\title{
The application of the loop-mediated isothermal amplification (LAMP) method for diagnosing Enterococcus hirae-associated endocarditis outbreaks in chickens
}

\author{
Beata Dolka ${ }^{{ }^{*}} \mathbb{D}$, Agata Anna Cisek $^{2}$ and Piotr Szeleszczuk ${ }^{1}$
}

\begin{abstract}
Background: Enterococcus hirae is considered a part of the normal intestinal biota of several domestic animals, including poultry. However, this species is also associated with infective endocarditis in chickens, a disease that leads to unexpected deaths and serious economical losses. Enterococcus hirae is identified predominantly with the use of conventional bacteriological methods, biochemical tests and PCR. Rapid, sensitive and specific methods for detecting $E$. hirae in clinical samples are required in poultry production. The aim of this study was to use the LoopMediated Isothermal Amplification (LAMP) for the identification and quantification of $E$. hirae in heart samples from broiler chickens.
\end{abstract}

Results: The specificity of the LAMP method was confirmed for 7 enterococcal strains and 3 non-enterococcal strains. E. hirae was detected in all of the 22 analyzed clinical bacterial isolates and in all of the 9 heart samples. Three sets of primers supported the detection of $E$. hirae with high sensitivity and specificity within one hour. The highest detection rate of a LAMP product was approximately $7 \mathrm{~min}$ for an E. hirae strain and $12 \mathrm{~min}$ for a positive heart sample. The detection limit for the E. hirae ATCC 10541 standard was $1.3 \times 10^{2}$ CFU ( $\left.43.4 \mathrm{fg}\right)$ or 13.8 copies of the E. hirae genome equivalent per reaction. The reaction was 10 -fold more sensitive than conventional speciesspecific PCR. The LAMP assay supported the determination of the E. hirae load in chicken hearts with endocarditis in field cases. The average number of E. hirae cells in hearts was $5.19 \times 10^{7} \mathrm{CFU} / \mathrm{g}$ of tissue, and the average number of $E$. hirae genome equivalents in hearts was $5.51 \times 10^{6}$ copies/g of tissue. Bacterial counts were significantly higher in the LAMP assay than in the standard plate count.

Conclusions: The LAMP assay is a useful diagnostic tool and an effective alternative to conventional methods for the detection of this enterococcal species. The sodA-based LAMP assay supported direct identification of E. hirae from pure cultures and heart samples without previous bacterial cultivation. This is the first study to apply the LAMP method for the purpose of diagnosing E. hirae-associated endocarditis in poultry.

Keywords: Broiler chickens, Endocarditis, Enterococcus hirae, LAMP, qPCR, CFU

\footnotetext{
* Correspondence: beata_dolka@sggw.pl

'Department of Pathology and Veterinary Diagnostics, Faculty of Veterinary

Medicine, Warsaw University of Life Sciences, Nowoursynowska 159c, 02-776

Warsaw, Poland

Full list of author information is available at the end of the article
}

(c) The Author(s). 2019 Open Access This article is distributed under the terms of the Creative Commons Attribution 4.0 International License (http://creativecommons.org/licenses/by/4.0/), which permits unrestricted use, distribution, and reproduction in any medium, provided you give appropriate credit to the original author(s) and the source, provide a link to the Creative Commons license, and indicate if changes were made. The Creative Commons Public Domain Dedication waiver (http://creativecommons.org/publicdomain/zero/1.0/) applies to the data made available in this article, unless otherwise stated. 


\section{Background}

Enterococcus hirae is one of the 58 known species of the genus Enterococcus. E hirae was first described as a new species in 1985 by Farrow and Collins in strains that had been previously referred to as Enterococcus faecium. These authors established the distinct taxonomic position of $E$. hirae as a species that is separate from $E$. casseliflavus, E. durans and E. faecium [1]. Enterococcus hirae is considered a part of normal intestinal biota and an opportunistic pathogen in birds and mammals [2-4]. In the group of enterococci that constitute normal poultry microbiota, E. hirae has been relatively rarely isolated from the intestines. Devriese et al. [5] demonstrated that $E$. hirae colonizes the small intestines of 3to 4-week-old chickens, and - less frequently - 12-weekold chickens, but the bacterium was not isolated from the crop or the cecum. In chickens from tropical regions, $E$. hirae was detected in cecal and cloacal swabs only in birds older than 8 weeks [6].

According to the literature, E. hirae is the fourth (2.7\%) most common Enterococcus species identified in poultry [7]. In a study where samples were composed of $97 \%$ hearts, E. hirae was detected in $4.6 \%$ of the samples (after E. faecalis - 74.7\%, E. faecium - 10.1\%, E. gallinarum - 5.5\%). Enterococcus hirae was isolated mainly from laying hens (CL) (8.3\%), turkeys (5.6\%) and broilers (CB) $(5.5 \%)$, but it was never detected in broiler breeder chickens (BB) [8]. According to other authors E. hirae was more prevalent in ducks (6.2\%) than in $\mathrm{CB}(3.6 \%)$, BB (2.4\%), CL (1.8\%) and turkeys (0.7\%) [7]. Enterococcus hirae was not detected in geese $[7,8]$. The mean age of birds at the time of $E$. hirae isolation was approximately 3 days in ducks, 4 days in BB, 12-13 days in $\mathrm{CB}$, 4 weeks in CL, and 6 weeks in turkeys [7]. Enterococcus hirae was not identified in chicks (1- to 5-day-old) in 9 diagnostically independent cases, but it was more frequently isolated from older chickens (5 days - 6 weeks) (48\%) [9].

According to the original reports from 1985, E. hirae was associated with growth depression in young chickens [1]. Saikia et al. [6] observed that this species could be potentially pathogenic in chickens younger than 1 week. Devriese et al. [10] were the first to determine that $E$. hirae could cause septicemia and focal necrosis of the brain in 3- to 8-day-old chicks. Cases of E. hirae septicemia were also noted in 10 species of psittacine birds [11]. Enterococcus hirae can cause encephalomalacia in 1 - to 2 -week-old broilers and layers [10, 12]. The bacterium should be also included in differential diagnoses of diarrhea in chicks [13] and osteomyelitis in broiler chickens [14]. Since the 1990s, E. hirae has been recognized as an important etiological agent of bacterial endocarditis in chickens [15-17]. The prevalence of $E$. hirae in the microbiome of chicken hearts with endocarditis is unknown. E. hirae infections are characterized by fibrinous thrombotic lesions in atrioventricular (AV) valves, less often in the lungs, the external ischiadic artery (arteria ischiadica externa), liver and brain vessels. Velkers et al. [17] detected Enterococci in 54\% of the examined hearts. The percentage of affected hearts was highest in 2- to 3-week-old (47\%) and 3- to 4-week-old broiler chickens (46\%). In another study, E. hirae was isolated from $42 \%$ of birds (20-days-old) [16]. Outbreaks of $E$. hirae-associated endocarditis can cause economic losses in poultry production. Mortality peaks in the second week of broiler grow-out. E. hirae endocarditis is responsible for $36 \%$ of broiler deaths in the grow-out period. Lameness is occasionally observed [17].

In young birds, E. hirae infections may lead to only a minor increase in mortality without specific clinical signs. Outbreaks are not always clearly defined and may remain unnoticed or may be attributed to poor chick quality [16]. For this reason, the etiological agent and the prevalence of the infection are often not identified. An accurate diagnosis of the infection is crucial to avoid unnecessary antibiotic use and to select the most appropriate therapy. In most cases, diagnosis is considerably delayed, which could explain the presence of severe cardiac lesions during necropsy. The present study highlights the importance of proper diagnosis of enterococcal infections in poultry.

E. hirae is a zoonotic pathogen, but it rarely causes infections in humans [2-4]. Most human cases involved bacteremia accompanied by severe illness, such as acute pyelonephritis, pancreatitis, cholangitis, severe urinary tract infections or spondylodiscitis [4, 18-20]. Three cases of human endocarditis caused by $E$. hirae have been reported to date [3, 21, 22].

Standard methods of enterococci identification rely on conventional culture-based approaches, including evaluations of colony morphology, Gram staining and analyses of biochemical properties [2]. Additional tests are required to identify $E$. hirae to species level. However, selected enterococci of avian origin are not always detected by commercially available automated identification systems. The problems associated with the phenotypic identification of E. hirae have prompted the development of more accurate molecular techniques. At present, E. hirae are identified with the use of PCR techniques based on the amplification of the $\operatorname{sodA}$ gene encoding superoxide dismutase $(\mathrm{Mn})$ and gene sequencing [23]. The detection of $E$. hirae by conventional culture- and biochemical-based assays is time-consuming, laborious and requires several days. PCR assays are more rapid than conventional methods, but they require agarose gel electrophoresis; therefore, the identification of $E$. hirae can be completed in a few hours.

In 2002, a new nucleic acid amplification method, loop-mediated isothermal amplification (LAMP), was 
described by Notomi et al. [24]. LAMP is based on an autocycling strand-displacement reaction which uses specific DNA polymerase (such as Bst, Bsm or Gsp) and a set of 4 primers (F3, B3, FIP, BIP) complementary to the target gene. Additional two loop-creating primers may be used to improve amplification [25]. DNA is amplified under isothermal conditions with high specificity, sensitivity, efficiency and speed. The LAMP technique has revolutionized the detection of poultry pathogens, and it is a highly useful tool for the rapid detection of selected viruses, bacteria, fungi and protozoa [26-33]. However, there are no published reports on the application of the LAMP method for the identification of $E$. hirae. In this study, the LAMP assay has been used to detect and quantify E. hirae responsible for endocarditis in broiler chickens. The LAMP technique was evaluated using a panel of bacterial DNA and heart samples from field outbreaks in broiler flocks. The results were compared with the outcomes of standard PCR and culture-based methods.

\section{Methods}

\section{Bacterial strains and heart samples}

A total of 22 field strains of $E$. hirae and 9 heart samples (tissue with lesions) from broiler chickens (CB) were analyzed. Each strain and heart represented a separate disease outbreak reported between 2011 and 2017 in Poland. All samples were obtained from the collection of the Division of Avian Diseases, Department of Pathology and Veterinary Diagnostics, Faculty of Veterinary Medicine of the Warsaw University of Life Sciences. Pursuant to the provisions of Polish and European Union law
(Journal of Laws of 2015, item 266; Directive 2010/63/ EU), the approval of the Animal Ethics Committee was not required for this study. Bacterial strains were isolated from heart samples suspected of enterococcal infection. Heart samples were collected during routine diagnostic necropsy of chickens from flocks suspected of E. hirae-associated endocarditis (Fig. 1). E. hirae was cultured from approximately $20-60 \%$ of hearts. Heart samples (valve fragments with heart blood) were plated onto Columbia agar supplemented with $5 \%$ sheep blood and onto Enterococcosel Agar plates containing esculin (Graso, Poland). They were incubated at $37^{\circ} \mathrm{C}$ for $24 \mathrm{~h}$ in a $\mathrm{CO}_{2}$-enriched atmosphere. Bacterial isolates were initially characterized based on analyses of colony morphology (transparent grey to white colonies), Gram staining (Gram-positive) and catalase production (negative). The preliminary identification of $E$. hirae was carried out in the API Rapid ID 32 STREP system (bioMérieux France). Clinical strains were confirmed by sequencing (Genomed, Warsaw, Poland). The sequences of 6 randomly selected isolates were deposited in GenBank (MF356372 - MF356377).

\section{DNA isolation from bacterial strains}

The DNA from clinical bacterial strains was extracted by the boiling lysis method. Single colonies were selected from Columbia agar (with $5 \%$ sheep blood) and suspended in $0.5 \mathrm{ml}$ of sterile water. The cell suspension was held in a boiling water-bath for $10 \mathrm{~min}$ to lyse the cells; it was chilled on ice for several seconds and centrifuged for $5 \mathrm{~min}$ at $10000 \mathrm{rpm}$. A supernatant $(1 \mu \mathrm{l})$ was used for LAMP and conventional PCR reactions.

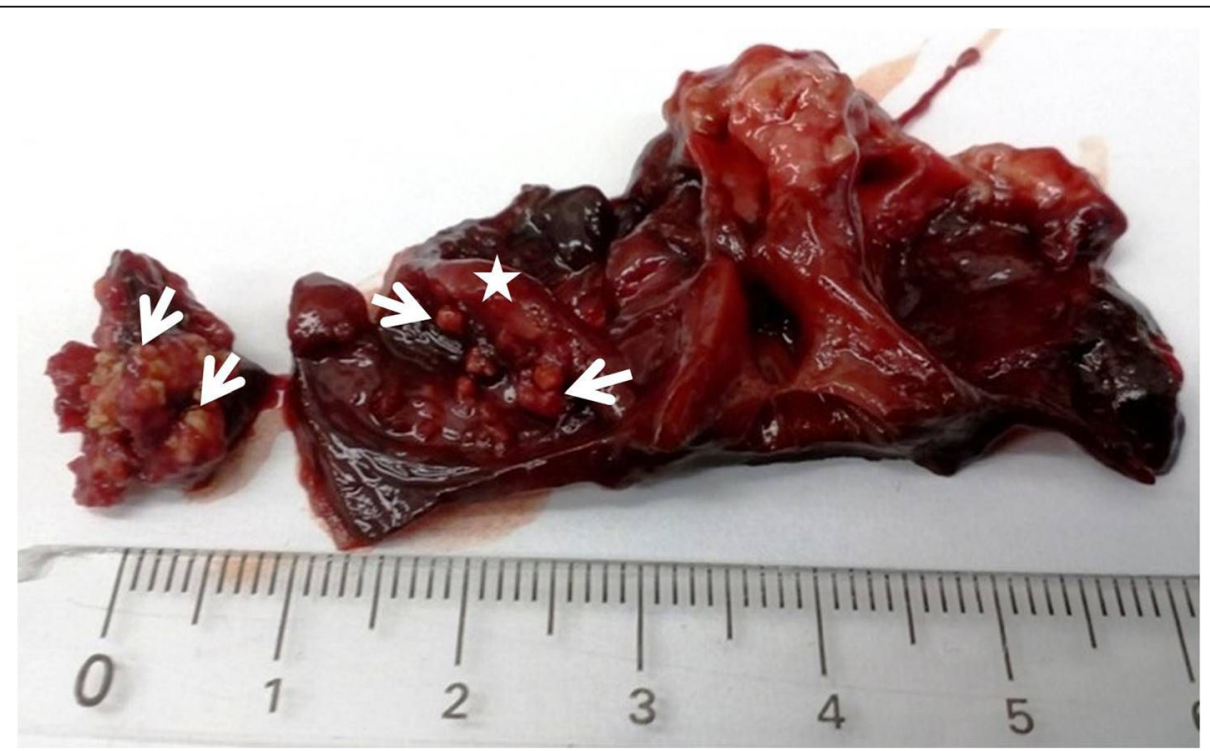

Fig. 1 The chicken heart with severe lesions (arrows) on the right atrioventricular valve (asterisk) associated with E. hirae infection 


\section{DNA isolation from heart samples}

The DNA from the affected heart samples was extracted using the Sherlock AX kit (A\&A Biotechnology, Gdańsk, Poland) with lysozyme-mutanolysin pretreatment. Briefly, $20 \mathrm{mg}$ specimens of heart samples with visible lesions were transferred to $1.5 \mathrm{ml}$ Eppendorf tubes, suspended in $300 \mu \mathrm{l}$ of sterile water, $60 \mu \mathrm{l}$ of lysozyme $(10 \mathrm{mg} / \mathrm{ml})$ and $5 \mu \mathrm{l}$ of mutanolysin $(10 \mathrm{U} / \mu \mathrm{l})$. The solution was mixed in a vortex and incubated in the Thermomixer Compact (Eppendorf AG, Germany) at $37{ }^{\circ} \mathrm{C}$ for $15 \mathrm{~min}$ with shaking at $600 \mathrm{rpm}$. The solution was combined with $300 \mu \mathrm{l}$ of lysis buffer L.1.4 and proteinase K (Sherlock AX, A\&A Biotechnology, Gdańsk, Poland). It was vortexed $(20 \mathrm{~s})$ and incubated in the thermomixer at $50{ }^{\circ} \mathrm{C}$ with vigorous shaking at $1400 \mathrm{rpm}$ for $60 \mathrm{~min}$ (until complete digestion). Samples were treated with $5 \mu \mathrm{l}$ of RNAse $(10 \mathrm{mg} / \mathrm{ml})$ for $5 \mathrm{~min}$ at room temperature to remove residual bacterial RNA. Subsequently, the isolation was continued according to the first step of the Sherlock AX protocol. The final DNA pellet was dissolved in $20 \mu \mathrm{l}$ of nuclease-free water (R0581, Thermo Fisher Scientific Inc., USA).

\section{LAMP assay}

The nucleotide sequences of the primers are shown in Table 1 (Novazym Polska s.c., Poznań, Poland). The primers were designed using LAMP Designer (OptiGene Ltd., UK) based on NCBI sequences of the sodA gene in E. hirae (GenBank number: EU02133). The location of the primers within a gene fragment is shown in Fig. 2 . The total reaction mixture $(12.5 \mu \mathrm{l})$ consisted of: $7.5 \mu \mathrm{l}$ of the Isothermal MasterMix (ISO-001 OptiGene Ltd. $\mathrm{UK}), 3 \mu \mathrm{l}$ of the primer mix, $1 \mu \mathrm{l}$ of nuclease-free water and $1 \mu \mathrm{l}$ of DNA. The primer mix consisted of: $0.5 \mu \mathrm{l}$ of F3, $0.5 \mu \mathrm{l}$ of B3, $2 \mu \mathrm{l}$ of FIP, $2 \mu \mathrm{l}$ of BIP, $1 \mu \mathrm{l}$ of LoopF and $1 \mu \mathrm{l}$ of LoopR, at $10 \mathrm{pmol} / \mu \mathrm{l}$ each. The LAMP assay was performed with the Stratagene Mx3005P QPCR instrument (Agilent Technologies Inc., Santa Clara, CA, USA) with a melting curve analysis step. The mixture was incubated for $80 \mathrm{cycles}$ of $65^{\circ} \mathrm{C}$ for $30 \mathrm{~s}$. Fluorescence was measured after each cycle in the FAM channel. For melting (dissociation) curve analysis, the temperature was increased gradually from $65^{\circ} \mathrm{C}$ to $95^{\circ} \mathrm{C}$ at the default rate of $0.2^{\circ} \mathrm{C} / \mathrm{s}$, and fluorescence data was collected continuously (all points) during the ramp. During the reaction, data were collected from two replicates, and the results were presented collectively.

Reaction time was assessed with and without loop primers to determine their influence on the speed of the LAMP assay. To confirm reaction accuracy, LAMP products were detected by separation in $2 \%$ agarose gel with ethidium bromide staining and were visualized under UV light (UVP, US). The presence of specific multiple ladder bands was considered a positive result. Finally, the LAMP product of E. hirae ATCC 10541 was confirmed by sequencing analysis. After gel electrophoresis, the shortest bands on agarose gel were cut out, purified with the GeneMATRIX Agarose-Out DNA Purification Kit (EURx, Gdańsk, Poland) and sequenced by Genomed (Warsaw, Poland). The obtained sequence fragments were analyzed using the NCBI BLAST Sequence Analysis Tool (https://blast.ncbi.nlm.nih.gov/ Blast.cgi).

\section{Specificity of the LAMP assay}

The specificity of the LAMP assay was evaluated using the DNA of 7 Enterococcus reference ATCC strains: $E$. casseliflavus 700,327, E. cecorum 43,198, E. durans 6056, E. faecalis 29,212, E. faecium 700,221, E. gallinarum ATCC 700425 and E. raffinosus ATCC 49464), as well as 3 non-E. hirae strains (E. coli 25,922, Staphylococcus aureus 25,923, Rimerella anatipestifer). E. hirae ATCC 10541 was used as positive control. Nuclease-free water was used as negative control (NTC-Non Template Control).

\section{Standard curve and sensitivity of the LAMP assay}

Two calibration methods were used to generate the standard curve. In the first method, quantification was based on the number of cells present in the bacterial suspension (colony-forming units, CFU) before DNA extraction. In the second method, bacteria were quantified in silico with the use of a calculator for determining the number of copies of a template (URI Genomics and

Table 1 Sequences of LAMP primers for detecting Enterococcus hirae (target sodA gene)

\begin{tabular}{lll}
\hline Primers name & Sequence $\left(5^{\prime}-3^{\prime}\right)$ & Base pair length \\
\hline F3 (forward outer primer) & CCTACAGATATCAAGACTGCTG & 22 \\
B3 (backward outer primer) & GCTGTTGAGTGATCGCTA & 19 \\
FIP (F1C + F2; forward inner primer) & ACCAGCATTGGTGCCATGAGTAATAATGGTGGCGGACAT & 40 (20 F1C, 20 F2) \\
BIP (B1C + B2; backward inner primer) & $\underline{\text { CGAACCAACTGGTGCAATTAAAGAAAATCTTCCTTAAATGTTGCAAAATC }}$ & 51 (25 B1C, 26 B2) \\
LoopF (loop forward primer) & TCCAGAAGAAAGAATGGTTGC & 23 \\
LoopB (loop reverse primer) & GCGATTGATGAACCTTTGGT & 21 \\
\hline
\end{tabular}

FIP consists of the F1c and F2 sequences; BIP consists of the B1c and B2 sequences. F1c and B1c were shown as underlined nucleotide sequences Amplicon size amplified with the outer primers F3/B3 is 248 bp (Novazym Poland s.c., Poznań) 


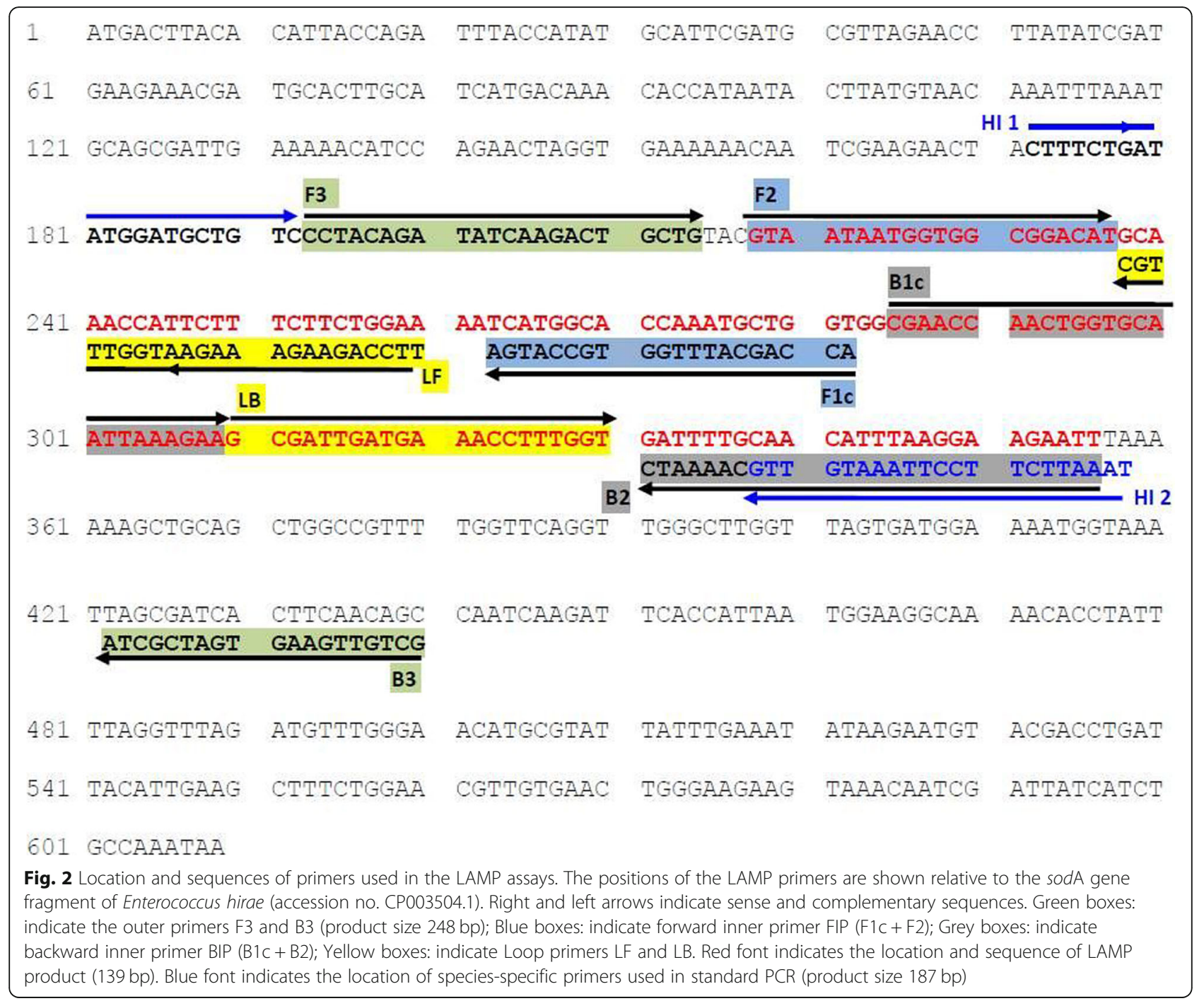

Sequencing Center) available online at http://cels.uri.edu/gsc/cndna.html [34]. The results were presented as genome equivalents (GE). The size of the $E$. hirae genome $(\sim 2.9 \mathrm{Mb})$ from the NCBI database was used in the calculations. According to the literature, $\operatorname{sodA}$ is probably a single copy gene [35]. The entire bacterial genomic DNA was extracted from $1.3 \times 10^{8} \mathrm{CFU} / \mathrm{ml}$ of $E$. hirae ATCC 10541 with the Genomic Mini AX Bacteria kit (A\&A Biotechnology, Gdynia, Poland). The counts (CFU) of E. hirae ATCC 10541 were determined by plating on Enterococcosel Agar plates (Graso, Poland). DNA concentration was measured in the Nanodrop 2000 system (Thermo Scientific, USA). The concentration of bacterial genomic DNA was converted to genome equivalents in silico. Subsequently, a 10-fold dilution series of the DNA extracted from $1.3 \times 10^{8} \mathrm{CFU} / \mathrm{ml}$ to $1 \mathrm{CFU} / \mathrm{ml}$ was prepared. Each dilution with a volume of $1 \mu \mathrm{l}$ was used in duplicate as a quantitative standard for Enterococcus. A standard curve was generated by plotting $\mathrm{Cq}$ values against the logarithmic values of bacterial counts ( $\log _{10}$ CFU equivalent and GE). The sensitivity of the LAMP technique was assessed with 10-fold serial dilutions $\left(10^{0}\right.$ to $\left.10^{-8}\right)$ of $E$. hirae ATCC 10541 DNA with a concentration of $43.4 \mathrm{ng} / \mu \mathrm{l}$ up to $0.434 \mathrm{fg} / \mu \mathrm{l}$, which corresponded to 0.138 to $1.38 \times 10^{7}$ genome copies per reaction.

\section{The sensitivity of LAMP vs. PCR}

The sensitivity of the LAMP technique and a standard PCR assay was compared with the use of the same DNA templates with identical concentrations and volumes. Two standard PCR assays were performed. The first assay involved outer primers F3/B3 (amplicon size 248 bp) from the LAMP test conducted in this study, and the second assay involved E. hirae-specific primers (amplicon size $187 \mathrm{bp}$ ) described by Jackson et al. [23] Both PCR assays were performed in a volume of $25 \mu \mathrm{l}$ containing $12.5 \mu$ of the DreamTaq ${ }^{\text {Tu }}$ Green PCR Master Mix (2x) mix (K1081, Thermo Fisher Scientific Inc., 
USA)., $0.5 \mu \mathrm{l}$ of each primer $(10 \mathrm{pmol} / \mu \mathrm{l}), 1 \mu \mathrm{l}$ of DNA and $10.5 \mu \mathrm{l}$ of water. The amplification profile was as follows: initial denaturation at $95^{\circ} \mathrm{C}$ for $4 \mathrm{~min}$, followed by 30 cycles of $95^{\circ} \mathrm{C}$ for $30 \mathrm{~s}, 55^{\circ} \mathrm{C}$ for $60 \mathrm{~s}, 72^{\circ} \mathrm{C}$ for $60 \mathrm{~s}$, and final extension at $72^{\circ} \mathrm{C}$ for $7 \mathrm{~min}$ [23]. The amplified DNA fragments were analyzed by electrophoresis in $1.2 \%$ $(w / v)$ agarose gel. The PCR products obtained with LAMP primers (F3/B3) for E. hirae ATCC 10541 and randomly selected heart samples were verified by sequencing.

\section{Detection of $E$. hirae in hearts by the standard plate count (SPC) method}

The results of the LAMP assay and conventional agar plate enumeration were compared based on E. hirae loads in the affected hearts. Heart samples were suspended in sterile water (ratio 1:10), and serial 10-fold dilutions were prepared in sterile water. Each dilution in the amount of $100 \mu \mathrm{l}$ was plated on Enterococcosel Agar (Graso, Poland). Three replicate plates for each dilution were inoculated, and the colony counts on each plate were averaged. The number of colony-forming units per gram (CFU/g) of heart tissue was calculated using standard laboratory methods.

\section{Statistical methods}

The Wilcoxon signed-rank test was used to determine statistically significant differences in E. hirae counts from LAMP and SPC assays. A two-tailed $p$-value of 0.05 was regarded as statistically significant. The agreement beyond chance between LAMP and PCR was assessed using Gwet's AC1 coefficient rather than Cohen's kappa to resolve the problem of unbalanced symmetrical marginal distribution of observations in the contingency table [36, 37]. Statistical analyses were performed in TIBCO Statistica 13.3 (TIBCO Statistics Inc.) and Microsoft Office Excel 2016.

\section{Results}

The direct detection of LAMP products was based on melting temperature profiles determined by melting curve analysis of the amplified products. A single peak in the melting curve at $\mathrm{Tm} 86-87^{\circ} \mathrm{C}$ was regarded as indicative of a set of pure, specific amplicons. The first amplified products of the sodA gene fragment from the reference strain of $E$. hirae were detected within $8 \mathrm{~min}$ with loop primers $\left(\mathrm{Cq} 16.13 ; \operatorname{Tm} 86.65^{\circ} \mathrm{C}\right)$, and within 18 min (Cq 35.55 ; $\operatorname{Tm} 86.65^{\circ} \mathrm{C}$ ) without loop primers (Fig. 3). The nucleotide sequence of the LAMP product of the control strain was highly similar (99\%) to E. hirae, and it was deposited in GenBank (MG581167).

\section{Specificity of the LAMP assay}

The LAMP assay demonstrated $100 \%$ specificity against different Enterococcus species and non-Enterococcus strains (Fig. 4a). Ladder-like DNA amplification products were detected only in $E$. hirae (positive LAMP reaction), and they were not identified in other strains (negative results) (Fig. 4b).

\section{The sensitivity of LAMP and conventional PCR assays}

The sensitivity of the LAMP assay was tested using 10-fold serial dilutions of $1 \mu \mathrm{l}$ of $E$. hirae ATCC 10541 DNA with a known number of colony counts and genome copies. Based on genome size and the concentration of genomic DNA, 43.4 ng of E. hirae ATCC 10541 DNA was equivalent to $1.38 \times 10^{7}$ genome copies. The detection limit of the LAMP assay was determined at $1.3 \times 10^{2} \mathrm{CFU}\left(43.4 \mathrm{fg}, 10^{-6}\right)$ or 13.8 copies of the $E$.

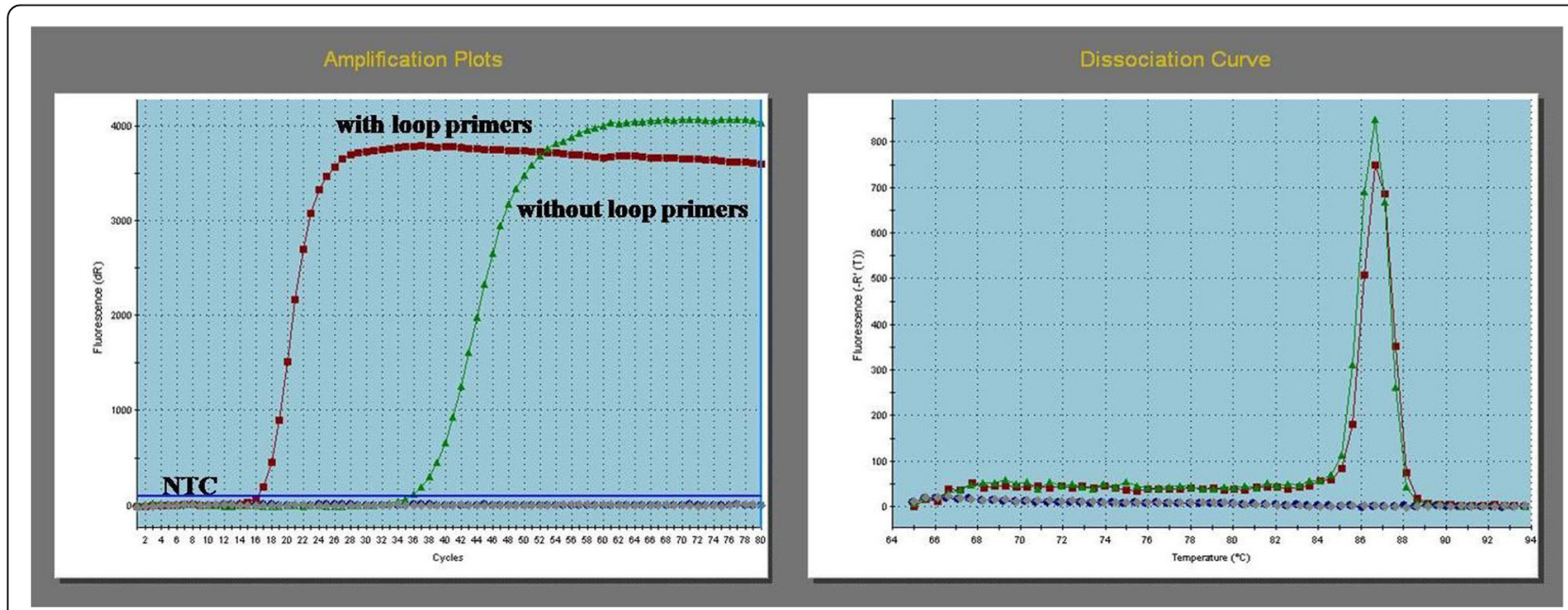

Fig. 3 LAMP amplification graph and dissociation curves for E. hirae ATCC 10541 generated by running the assays with two and three sets of primers. Assay with the loop primers resulted in $\mathrm{Cq}$ value of 16.13 , and melting peak at $\mathrm{Tm} 86.65^{\circ} \mathrm{C}$, whilst the one without the loop primers $\mathrm{Cq}$ value of 35.55 , and melting peak at $\operatorname{Tm} 86.65^{\circ} \mathrm{C}$ 

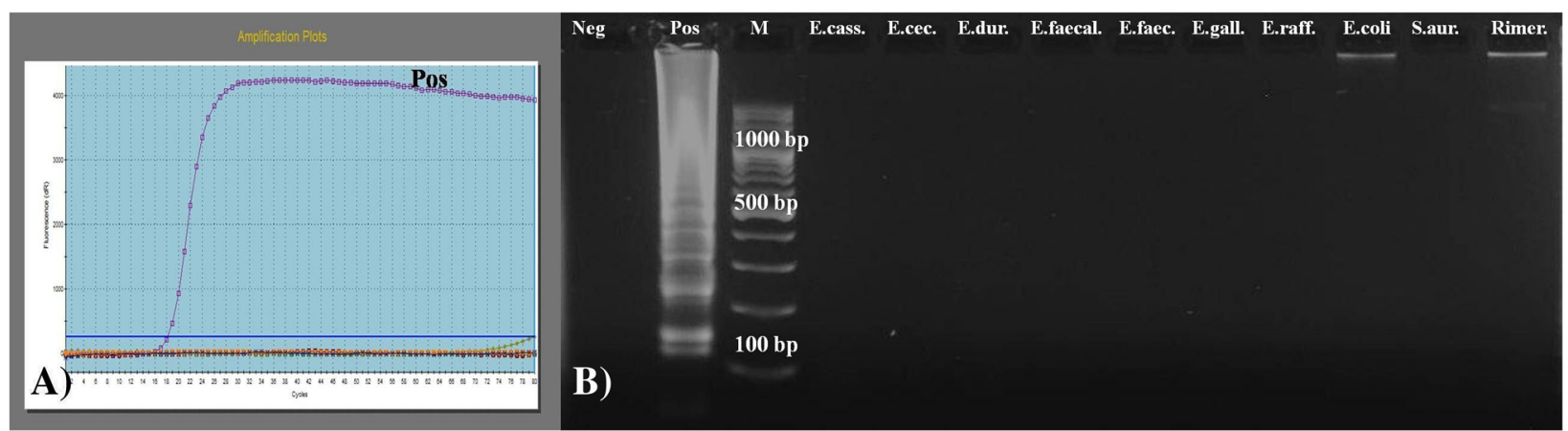

Fig. 4 Amplification graph (a) and agarose gel $(1.5 \% \mathrm{~W} / \mathrm{V})$ electrophoresis of LAMP products $(\mathbf{b})$ amplified from genomic DNA of E. hirae, other Enterococcus and non-Enterococcus strains. Lane 1: Neg-negative control, Lane 2: Pos-positive control, E. hirae (ladder-like band pattern), Lane 3: M100-bp DNA ladder (Thermo Fisher Scientific Inc., USA), Lane 4-13: E. casseliflavus, E. cecorum, E. durans, E. faecalis, E. faecium, E. gallinarum, E. raffinosus, Escherichia coli, Staphylococcus aureus, Rimerella anatipestifer

hirae genome equivalent/reaction, and it was identical to that noted in the electrophoresis assay (Fig. 5a). The efficiency of the LAMP assay was $100 \%$. The smallest detectable amount of E. hirae ATCC 10541 in the LAMP assay was obtained within $18 \mathrm{~min}$, and the highest concentration was obtained within $8 \mathrm{~min}$.

The detection limit of conventional PCR with F3/B3 primers was similar to that of the LAMP assay, but the band for the $10^{-6}$ dilution appeared to be weak-positive (Fig. 5b). Conventional PCR with a set of E. hirae-specific primers had a detection limit of $1.3 \times 10^{3} \mathrm{CFU}$ (434 $\mathrm{fg}, 10^{-5}$ ) or 138 genomic copies/reaction (Fig. 5c).

\section{The applicability of LAMP for analyses of E. hirae strains and heart samples}

LAMP products were detected in all of the tested 22 bacterial strains and all of the 9 heart tissue samples. The standard curve for LAMP-assisted quantification of bacterial DNA from hearts is presented in Fig. 6. Quantification results were also expressed in genome equivalents (GE) per gram of affected heart tissue (Table 2). In the LAMP assay, the average number of $E$. hirae equivalent genomes in hearts was determined at $5.51 \times 10^{6}$ copies/g.

Melting peaks were determined in the range of 86.05$87.06^{\circ} \mathrm{C}$ (Fig. 7a) for field strains and in the expected range of $86-87^{\circ} \mathrm{C}$ for hearts (Fig. 7b). Non-specific peaks were not detected for the tested primer sets. In bacterial strains and heart samples, the results of the LAMP assay were confirmed by the presence of a characteristic ladder-like pattern in agarose gel electrophoresis (Fig. 7c, d) and by sequencing. Standard PCR assays were less sensitive than LAMP. Twenty-one of the 22 analyzed isolates $(95.5 \%)$ produced positive results in the PCR assay with F3/B3 primers, and one isolate (4.5\%) was negative (Fig. 8a). Nineteen isolates (86.4\%) produced positive results in PCR with species-specific

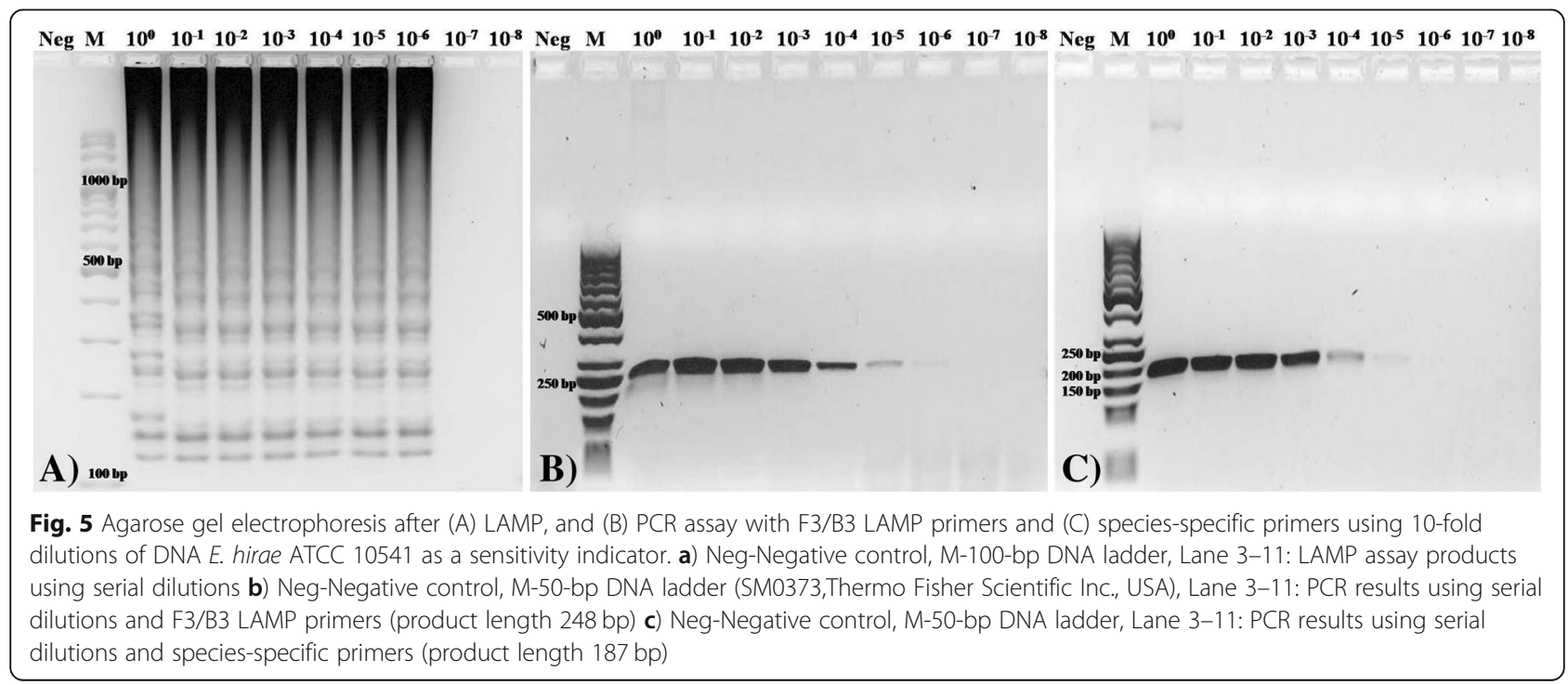




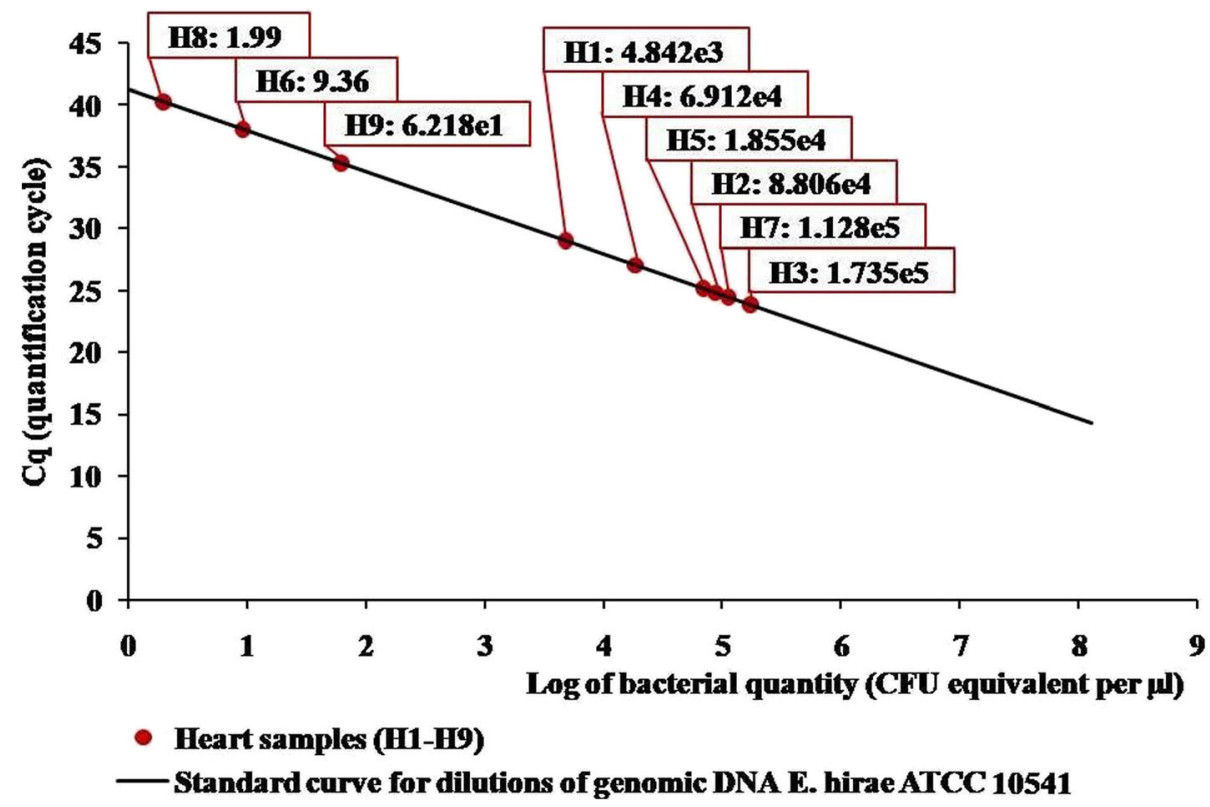

Fig. 6 Results of LAMP assay for E. hirae load in affected chicken heart samples (log of CFU/ $\mu$ l of DNA template). Results for hearts were visualized on standard curve, which was generated from a dilution series of genomic DNA E. hirae ATCC 10541 by plotting the quantification cycle values (Cq) against the log of the bacterial quantity ( $\log _{10}$ CFU equivalent per $\mu$ l of DNA template). Linear equation: $y=-3.319 x+41.23$. $R^{2}$ $=0,99$. Amplification factor $=2.00$

primers, 2 isolates produced weak bands, and 3 isolates (13.6\%) were negative (Fig. 8b).

The results of the LAMP test were consistent with the PCR results for heart samples obtained with LAMP primers and E. hirae-specific primers (Fig. 8c, d). The

Table 2 Detection of E. hirae in hearts of chickens representing different disease outbreaks

\begin{tabular}{llll}
\hline No. of affected heart & LAMP - cells/g & CFU counting & LAMP - GE/g \\
\hline H3 & $1.74 \times 10^{8}$ & $4.0 \times 10^{6}$ & $1.84 \times 10^{7}$ \\
H7 & $1.13 \times 10^{8}$ & $5.0 \times 10^{6}$ & $1.2 \times 10^{7}$ \\
H2 & $8.81 \times 10^{7}$ & $3.53 \times 10^{7}$ & $9.35 \times 10^{6}$ \\
H4 & $6.91 \times 10^{7}$ & $2.0 \times 10^{6}$ & $7.34 \times 10^{6}$ \\
H5 & $1.86 \times 10^{7}$ & $8.0 \times 10^{6}$ & $1.97 \times 10^{6}$ \\
H1 & $4.84 \times 10^{6}$ & $3.3 \times 10^{6}$ & $5.14 \times 10^{5}$ \\
H9 & $6.22 \times 10^{4}$ & $7.67 \times 10^{2}$ & $6.6 \times 10^{3}$ \\
H6 & $9.36 \times 10^{3}$ & $2.33 \times 10^{5}$ & $9.94 \times 10^{2}$ \\
H8 & $1.99 \times 10^{3}$ & $1.0 \times 10^{4}$ & $2.12 \times 10^{2}$ \\
Mean & $5.19 \times 10^{7} *$ & $6.43 \times 10^{6} *$ & $5.51 \times 10^{6}$ \\
SD & $6.27 \times 10^{7}$ & $1.11 \times 10^{7}$ & $4.61 \times 10^{6}$ \\
\hline
\end{tabular}

LAMP - cells/g - bacterial cell number ( $\log _{10}$ CFU equivalent) determined by LAMP

LAMP - GE/g - genome equivalents of $E$. hirae per $g$ of heart sample calculated by LAMP

CFU - total viable E. hirae counts per g determined on selective agar after $24 \mathrm{~h}$ incubation

*statistical significance $(p=0.028)$ between bacterial cell number determined by LAMP and CFU (LAMP - cells/g vs. CFU counting)

The bacterial number of and genome equivalents were determined in $1 \mathrm{~g}$ of heart samples by LAMP and conventional plate-counting method agreement beyond chance between LAMP and PCR is presented in Table 3 . The newly generated sequence fragments from PCR with F3/B3 LAMP primers confirmed the high homology of $E$. hirae sequences. The obtained sequences were deposited in GenBank under accession numbers MG581168 (control strain) and MG581169 (heart sample). The fastest detection time of a LAMP product was approximately $7 \mathrm{~min}$ for $E$. hirae strains and $12 \mathrm{~min}$ for heart samples. The PCR assay was completed in approx. $2 \mathrm{~h}$, and agarose gel electrophoresis was required to detect the amplified products.

Enumeration of $E$. hirae in heart samples by the standard plate count (SPC) method

All LAMP-positive heart samples were examined for bacterial counts on plate agar. The results of $E$. hirae quantification in heart samples by LAMP and culture assays are presented in Table 2 .

\section{Discussion}

Infections associated with enterococci often lead to growth depression and higher early mortality without specific clinical symptoms $[1,16]$. Enterococcus hirae is not the only cause of endocarditis in chickens, and other pathogenic agents include Enterococcus faecalis, E. faecium, E. durans, Staphylococcus aureus, Staphylococcus simulans, Streptococcus gallinaceus, Streptococcus pluranimalium, Avibacterium endocarditidis, Gallibacterium anatis and Helcococcus ovis [38-43]. For this reason, 


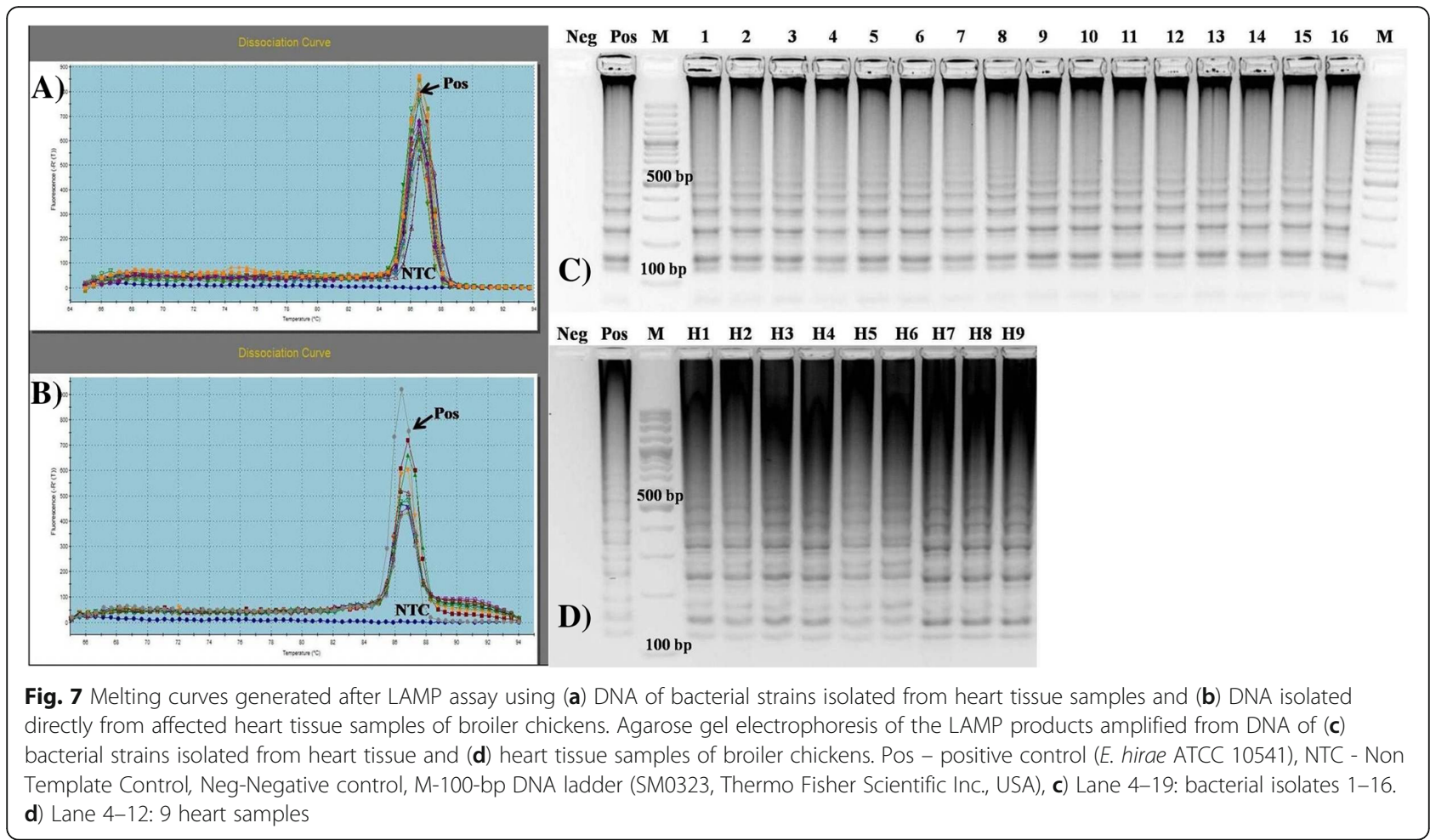

species-specific methods are needed for rapid and accurate identification of the causative agent. In this study, the LAMP method was used to diagnose Enterococcus hirae infections in poultry. Other authors relied on the LAMP technique to detect bacterial pathogens such as Salmonella spp., Streptococcus spp., Mycoplasma synoviae, Riemerella anatipestifer and Gallibacterium anatis in poultry [29, 30, 42, 44, 45]. A review of the literature revealed that the previously described LAMP assays for Enterococcus spp. had been developed primarily to target enterococci in water $[46,47]$. Kato et al. [48] demonstrated that LAMP was a useful technique for the rapid detection of $E$. faecalis and for diagnosing persistent endodontic infections. In the LAMP assays for detecting bacteria responsible for endocarditis, bacteria from the samples had to be previously cultured and DNA had to be isolated from a pure culture $[49,50]$. In other studies, bacteria (including the causative agents of endocarditis, but not $E$. hirae) were used directly in the LAMP test without prior culturing $[48,51,52]$. In this study, $E$. hirae were detected in clinical isolates and heart tissue samples for the first time with the use of the LAMP assay. The melting temperature of specific amplicons was determined at $86-87^{\circ} \mathrm{C}$. Positive reactions were further confirmed by agarose gel electrophoresis and sequencing. The specificity of the LAMP assay for E. hirae was confirmed in a reaction with DNA samples from other enterococcal and non-enterococcal species.
Loop primers were applied to shorten reaction time. Nagamine et al. [25] demonstrated that loop primers accelerated LAMP. In our study, the LAMP assay with loop primers supported product detection in the first 10 min of amplification. In LAMP assays without loop primers, the product was detected around $10 \mathrm{~min}$ later. Similarly to our studies, the highest available concentration of bacterial DNA in LAMP with loop primers was determined within approximately $10 \mathrm{~min}$ [42]. In the LAMP assay, the sodA gene was amplified within up to $60 \mathrm{~min}$. The LAMP test was clearly faster than conventional PCR. Similar observations were made in a LAMP assay for the rapid detection of E. faecalis [48].

The detection limit of the LAMP assay was $1.3 \times 10^{2}$ CFU, which indicates that LAMP was an effective technique for the detection and quantification of $E$. hirae in samples. Based on a review of the literature, Martzy et al. [47] concluded that the LAMP method can reliably detect 130 copies of E. faecalis target DNA per reaction within $45 \mathrm{~min}$. In our study, the detection limit ( $43.4 \mathrm{fg}$ ) was approximately twice lower than that reported by Kato et al. [48] for E. faecalis (100 fg/tube). Taking into account the concentration $(\mathrm{ng} / \mu \mathrm{l})$ and volume $(1 \mu \mathrm{l} / \mathrm{reac}-$ tion) of the reference DNA in the LAMP assay in this study, the detection limit was lower than that noted for G. anatis strains in LAMP and qPCR tests [42].

According to the literature, the bacterial sensitivity of the LAMP assay can be 10 - to 1000 -fold higher relative 

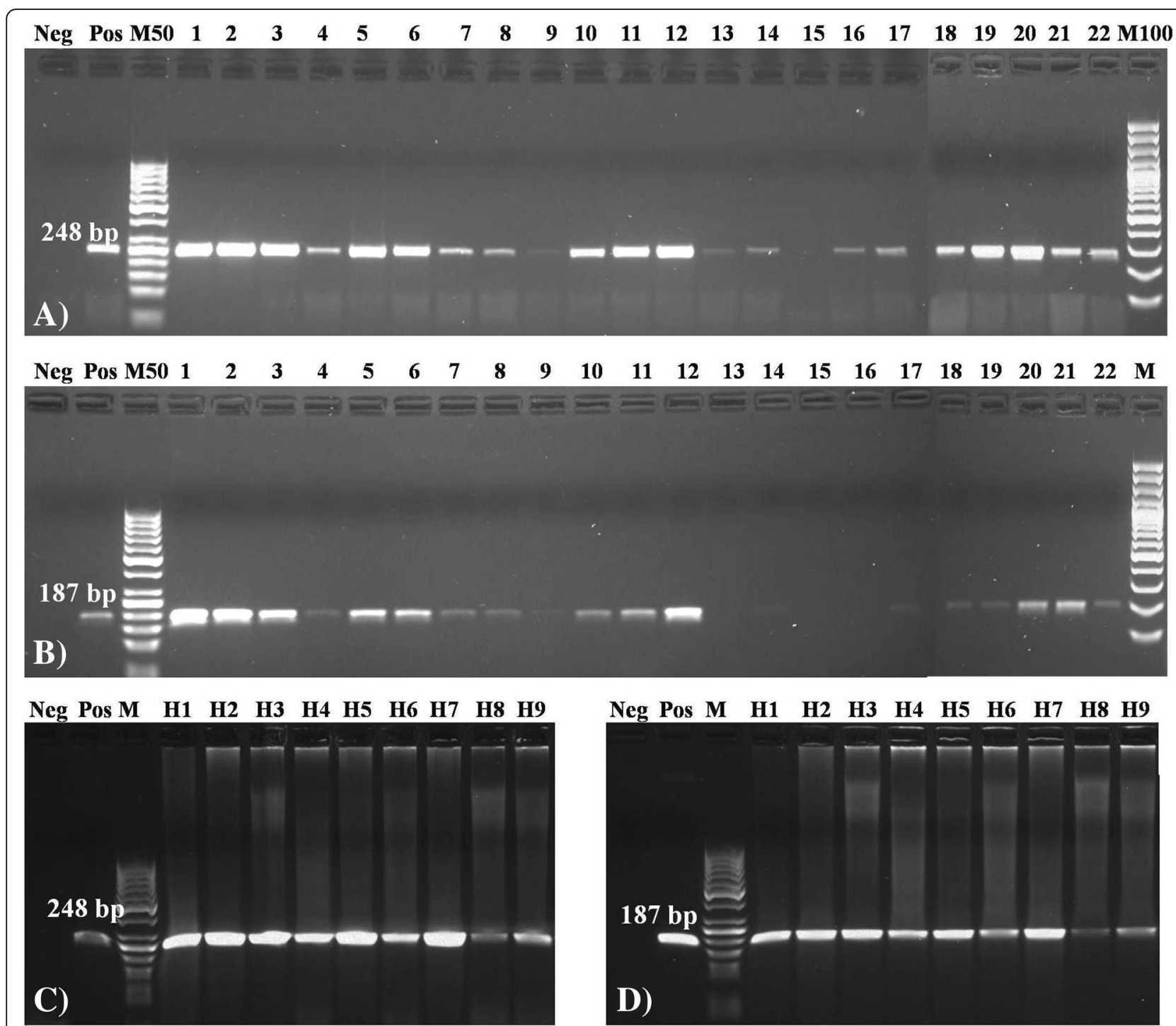

Fig. 8 Agarose gel electrophoresis showing the PCR products generated using DNA of bacterial isolates and (a) F3/B3 LAMP primers or (b) species-specific primers, and showing the PCR products generated using DNA isolated directly from the heart tissue samples and (c) F3/B3 LAMP primers or (d) species-specific primers. Neg-Negative control, Pos-Positive control, M-50-bp or 100 bp DNA ladder (Thermo Fisher Scientific Inc., USA), a), b) Lane 3-11: 22 bacterial isolates. c), d) Lane 4-12: 9 heart tissue samples

Table 3 The agreement between LAMP assay and two standard PCRs (PCR with F3/B3 LAMP primers and PCR with speciesspecific primers)

\begin{tabular}{ll}
\hline Combination of tests & AC1 \\
\hline LAMP vs. PCR with F3/B3 LAMP primers $^{a}$ & $95.4 \%(86.1-100 \%)$ \\
LAMP vs. PCR with species-specific primers $^{\text {b }}$ & $84.4 \%(68.0-100 \%)$ \\
PCR with F3/B3 LAMP primers vs. PCR & $89.1 \%(74.7-100 \%)$ \\
with species-specific primers & \\
\hline AC1:
\end{tabular}

AC1: the first-order agreement coefficient

aLAMP primers from this study

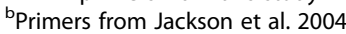

to PCR, and the LAMP test can be equally or more sensitive than real-time PCR [46, 47, 53-55]. In this study, the sensitivity parameters of LAMP and conventional PCR were compared in 10-fold serial dilutions of $E$. hirae ATCC 10541 template DNA. The sensitivity of the LAMP assay was comparable to that of conventional PCR with F3/B3 LAMP primers only, but agarose gel electrophoresis revealed that the minimum detectable dilution $\left(10^{-6}\right)$ produced a barely visible band in the PCR assay. The sensitivity of the LAMP test for E. hirae was 10 -fold higher relative to PCR with species-specific primers. E. hirae DNA was detected in heart samples with a generally small number of copies. PCR with F3/ B3 primers and species-specific primers confirmed that 
LAMP amplified the correct target and was a highly specific technique for target amplification. These observations indicate that LAMP is a more effective method than PCR for detecting $E$. hirae in samples where lower bacterial counts are expected. Unlike standard PCR (with LAMP primers or species-specific primers), LAMP produced positive results for all $E$. hirae isolates and heart samples affected by $E$. hirae. The agreement beyond chance between LAMP and PCR was very high (>80\%), which indicates that these techniques can be used interchangeably. However, our results should be interpreted with caution due to the very small number of negative samples screened in each test. Further large-scale research is required to fully substantiate these results.

In an experimental challenge study, Chadfield et al. [56] induced endocarditis in intravenously inoculated 4-week-old chickens by administering approximately $10^{8} \mathrm{CFU}$ of a clinical strain of $E$. hirae. The inoculation with $E$. hirae via brachial and jugular veins produced culture-positive heart samples in 35 and $73 \%$ of the birds, respectively. Cardiac lesions included valvular endocarditis and were observed in 20 and $55 \%$ of the birds infected via brachial and jugular veins, respectively. However, bacterial counts in the affected tissues have not been investigated to date. In this study, the LAMP technique was used to estimate $E$. hirae loads in the hearts of commercial chickens which represented separate disease outbreaks. The variations in bacterial counts in hearts $\left(10^{3}-10^{8}\right)$ could be attributed to different stages of infection in the examined flocks or differences in the pathogenic potential of E. hirae isolates. In this study, the bacterial load in the affected hearts determined by the LAMP method was compared with SPC results. The LAMP assay revealed significantly higher bacterial counts than SPC. The mean counts of viable $E$. hirae in hearts were approximately 8.1 times lower in SPC than in the LAMP test. Unlike SPC where only viable bacteria (replicating cells) are detected, the LAMP test and conventional qPCR amplify the DNA of both live and dead cells because DNA remains stable after bacterial death. The LAMP assay was essential for the accurate enumeration of $E$. hirae in tissue specimens. However, the main limitation of the LAMP test could be its inability to discriminate between live and dead cells. In this study, the lowest $E$. hirae counts determined in hearts by standard plating were 6 times higher than the detection limit of the LAMP test. Our results indicate that the LAMP assay could be helpful in overcoming certain limitations of conventional phenotypic procedures and plate-based enumeration for the detection of E. hirae.

Obviously, the applicability of the LAMP assay is limited to the detection, identification and quantification of E. hirae, and it cannot discriminate between clinical and commensal (normal) isolates. It is difficult to determine whether an isolate is the cause of an infection or whether it is non-pathogenic and is detected in samples due to contamination. Each isolation should be correlated with the health status and clinical signs in poultry. Predisposing factors could be involved in the establishment of infection. This is in contrast to other studies where predisposing factors were not evident in chickens prior to infection [56]. The properties responsible for the pathogenic potential of clinical E. hirae strains have not been elucidated to date. The differences between normal and pathogenic $E$. hirae have not been identified either. Further research is needed to characterize clinical $E$. hirae isolates, especially in relation to the presence of virulence factors.

\section{Conclusions}

To the best of our knowledge, this is the first report to describe the applicability of a $\operatorname{sodA-based~LAMP~assay~}$ for the detection of Enterococcus hirae. It is also the first study to evaluate the applicability of the LAMP assay for the quantification of $E$. hirae in affected chicken heart samples. The LAMP method supported the identification and quantification of bacteria in DNA samples isolated directly from heart tissue without prior cultivation. The LAMP technique enabled fast, specific and sensitive quantification, and it can be applied as an alternative molecular diagnostic tool detecting $E$. hirae in veterinary samples. The LAMP assay may facilitate diagnosis of infective endocarditis in poultry, thus contributing to differential diagnosis and the selection of the appropriate treatment. In this study, the LAMP assay was successfully used to diagnose E. hirae-associated endocarditis in broiler chickens.

\section{Abbreviations \\ CB: Chicken broiler flocks (commercial broilers); CFU: Colony-forming unit; GE: Genome equivalents; LAMP: Loop-Mediated Isothermal Amplification; NTC: Non-Template Control; SPC: Standard plate count method; Tm: Melting temperature}

\section{Acknowledgements}

The authors would like to thank Michał Czopowicz, DVM PhD for statistical assistance. The authors are grateful to Anna Kolińska and Adam Burzyński of Novazym Poland s.c., Poznań for their help. The authors also wish to express gratitude to veterinary laboratories and veterinary practitioners for help in collecting samples for E. hirae analyses: Lab-Vet Sp. z o.o. Tarnowo Podgórne, Gabinet Weterynaryjny "Gallus" Sylwester Barabasz, "Spec-Drób" Mariusz Lorek, Mirosław Berezowski. Preliminary data were presented during the scientific conference entitled "Current problems in poultry pathology", held on 29-30 June 2017 in Wroclaw, Poland.

\section{Funding}

This work was funded by internal grant in the Department of Pathology and Veterinary Diagnostics, Faculty of Veterinary Medicine of the Warsaw University of Life Sciences in Poland (decision No. 505-10-023700-N0017699). The costs of manuscript publication were funded by KNOW (Leading National Research Centre) Scientific Consortium "Healthy Animal - Safe Food", decision of Ministry of Science and Higher Education No. 05-1/ 
KNOW2/2015. The funders had no role in the study design, data collection, analysis, and interpretation of data, and in writing the manuscript or decision to publish.

\section{Availability of data and materials}

The datasets supporting our findings are included in the article.

\section{Authors' contributions}

$\mathrm{BD}$ conceived the presented idea, coordinated the study, collected strains and samples, carried out LAMP and PCR assays, analyzed the results and interpreted the data, and wrote the manuscript. AAC provided helpful suggestions, initiated stimulating discussions and participated in the interpretation of results. PS co-initiator of the study, consulted the study project and results, input in study coordination. All authors read and approved the final manuscript

\section{Ethics approval and consent to participate}

Poultry samples were collected for laboratory diagnosis in line with good clinical practice standards, Polish ethical guidelines (Journal of Laws, 2015, item 266) and animal welfare regulations. This study did not require the approval of the Ethics Committee of the Warsaw University of Life Sciences.

\section{Consent for publication}

Not applicable.

\section{Competing interests}

The authors declare that they have no competing interests.

\section{Publisher's Note}

Springer Nature remains neutral with regard to jurisdictional claims in published maps and institutional affiliations.

\section{Author details}

'Department of Pathology and Veterinary Diagnostics, Faculty of Veterinary Medicine, Warsaw University of Life Sciences, Nowoursynowska 159c, 02-776 Warsaw, Poland. ${ }^{2}$ Department of Preclinical Sciences, Faculty of Veterinary Medicine, Warsaw University of Life Sciences, Ciszewskiego 8, 02-786 Warsaw, Poland.

\section{Received: 19 February 2018 Accepted: 15 February 2019}

\section{Published online: 21 February 2019}

\section{References}

1. Farrow JAE, Collins MD. Enterococcus hirae, a new species that includes amino acid assay strain NCDO 1258 and strains causing growth depression in young chickens. Int J Food Microbiol. 1985;35:73-5.

2. Devriese LA, Kerckhove AV, Kilpper-Bälz R, Schleifer KH. Characterization and identification of Enterococcus species isolated from the intestines of animals. Int J Syst Bacteriol. 1987;37:257-9.

3. Poyart C, Lambert T, Morand P, Abassade P, Quesne G, Baudouy Y, TrieuCuot P. Native valve endocarditis due to Enterococcus hirae. J Clin Microbiol. 2002;40:2689-90.

4. Dicpinigaitis PV, De Aguirre M, Divito J. Enterococcus hirae bacteremia associated with acute pancreatitis and septic shock. Case Rep Infect Dis. 2015;2015:123852. https://doi.org/10.12013/2015/123852.

5. Devriese LA, Hommez J, Wijfels R, Haesebrouck F. Composition of the enterococcal and streptococcal intestinal flora of poultry. J Appl Bacteriol. 1991:71:46-50

6. Saikia PK, Devriese LA, Kalita CC, Haesebrouck F, Dutta GN. Composition of the enterococcal intestinal flora of chickens in a tropical area. Lett Appl Microbiol. 1994;19:436-7.

7. Dolka B, Gołębiewska-Kosakowska M, Krajewski K, Kwieciński P, Nowak T, Szubstarski J, Wilczyński J, Szeleszczuk P. Occurrence of Enterococcus spp. in poultry in Poland based on 2014-2015 data. Med Weter. 2017;3:193-256.

8. Stępień-Pyśniak D, Marek A, Banach T, Adaszek Ł, Pyzik E, Wilczyński J, Winiarczyk S. Prevalence and antibiotic resistance of Enterococcus strains isolated from poultry. Acta Vet Hung. 2016;64:148-63.

9. Wilczyński J, Wystalska D. Lekowrażliwość bakterii izolowanych od chorych kurcząt brojlerów pochodzących z ferm zlokalizowanych w województwie wielkopolskim. Cz II Enterococcus spp Polskie Drobiarstwo. 2016;2:52-7.
10. Devriese LA, Ducatelle R, Uyttebroek E, Haesebrouck F. Enterococcus hirae infection and focal necrosis of the brain of chicks. Vet Rec. 1991;129:316.

11. Devriese LA, Chiers K, De Herdt P, Vanrompay D, Desmidt M, Ducatelle R, Haesebrouck F. Enterococcus hirae infections in psittacine birds: epidemiological, pathological and bacteriological observations. Avian Pathol. 1995;24:523-31.

12. Randall CJ, Wood AM, MacKenzie G. Encephalomalacia in first-week chicks Vet Rec. 1993;132:419.

13. Kondo H, Abe N, Tsukuda K, Wada Y. Adherence of Enterococcus hirae to the duodenal epithelium of chicks with diarrhoea. Avian Pathol. 1997;26:189-94.

14. Kolbjørnsen $\varnothing$, David B, Gilhuus M. Bacterial osteomyelitis in a 3-week-old broiler chicken associated with Enterococcus hirae. Vet Pathol. 2011;48:1134-7.

15. McNamee PT, King DC. Endocarditis in broiler breeder rearers due to Enterococcus hirae. Vet Rec. 1996;138:240.

16. Chadfield MS, Christensen JP, Juhl-Hansen J, Christensen H, Bisgaard M. Characterization of Enterococcus hirae outbreaks in broiler flocks demonstrating increased mortality because of septicemia and endocarditis and/or altered production parameters. Avian Dis. 2005;49:16-23.

17. Velkers FC, van de Graaf-Bloois L, Wagenaar JA, Westendorp ST, van Bergen MA, Dwars RM, Landman WJ. Enterococcus hirae-associated endocarditis outbreaks in broiler flocks: clinical and pathological characteristics and molecular epidemiology. Vet Q 2011;31:3-17.

18. Canalejo E, Ballesteros R, Cabezudo J, García-Arata Ml, Moreno J. Bacteraemic spondylodiscitis caused by Enterococcus hirae. Eur J Clin Microbiol Infect Dis. 2008:27:613-5.

19. Chan TS, Wu MS, Suk FM, Chen CN, Chen YF, Hou YH, Lien GS. Enterococcus hirae-related acute pyelonephritis and cholangitis with bacteremia: an unusual infection in humans. Kaohsiung J Med Sci. 2012;28:111-4. https:/ doi.org/10.1016/j.kjms.2011.06.027.

20. Pãosinho A, Azevedo T, Alves JV, Costa IA, Carvalho G, Peres SR, Baptista T, Borges F, Mansinho K. Acute pyelonephritis with bacteremia caused by Enterococcus hirae: a rare infection in humans. Case Rep Infect Dis. 2016; 2016:4698462. https://doi.org/10.12013/2016/4698462.

21. Talarmin JP, Pineau S, Guillouzouic A, Boutoille D, Giraudeau C, Reynaud A, Lepelletier D, Corvec S. Relapse of Enterococcus hirae prosthetic valve endocarditis. J Clin Microbiol. 2011:49:1 182-4. https://doi.org/10.1128/JCM. 02049-10.

22. Anghinah $R$, Watanabe $R G$, Simabukuro MM, Guariglia C, Pinto LF, Gonçalves DC. Native valve endocarditis due to Enterococcus hirae presenting as a neurological deficit. Case Rep Neurol Med. 2013:636070. https://doi.org/10.12013/2013/636070.16.

23. Jackson CR, Cray F-, PJ BJB. Use of a genus- and species-specific multiplex PCR for identication of enterococci I Clin Microbiol. 2004:42:3558-65.

24. Notomi T, Okayama H, Masubuchi $\mathrm{H}$, Yonekawa T, Watanabe K, Amino N, Hase T. Loop-mediated isothermal amplification of DNA. Nucleic Acids Res. 2000;28:e63.

25. Nagamine K, Hase T, Notomi T. Accelerated reaction by loop-mediated isothermal amplification using loop primers. Mol Cell Probes. 2002;16:223-9.

26. Deng X, Oi X, Gao Y, Wang Y, Oin L, Gao H, Gao L, Wang X. Development of a loop-mediated isothermal amplification method for rapid detection of reticuloendotheliosis virus. J Virol Methods. 2010;168:82-6. https://doi.org/ 10.1016/j.jviromet.2010.04.021.

27. Huang $\mathrm{CH}$, Lai GH, Lee MS, Lin WH, Lien YY, Hsueh SC, Kao JY, Chang WT, Lu TC, Lin WN, Chen HJ, Lee MS. Development and evaluation of a loopmediated isothermal amplification assay for rapid detection of chicken anaemia virus. J Appl Microbiol. 2010;108:917-24. https://doi.org/10.1111/j. 1365-2672.2009.04481.

28. Dinh DT, Le MT, Vuong CD, Hasebe F, Morita K. An updated loop-mediated isothermal amplification method for rapid diagnosis of $\mathrm{H} 5 \mathrm{~N} 1$ avian influenza viruses. Trop Med Health. 2011;39:3-7. https://doi.org/10.2149/tmh.2010-21.

29. Han X, Ding C, He L, Hu Q, Yu S. Development of loop-mediated isothermal amplification (LAMP) targeting the GroEL gene for rapid detection of Riemerella anatipestifer. Avian Dis. 2011;55:379-83.

30. Burzyński A, Jankowska M. Amplifikacja in vitro wybranych odcinków DNA i RNA metodą loop-mediated isothermal AMPlification (LAMP). Novazym. 2014:4:1-27.

31. Woźniakowski G, Samorek-Salamonowicz E. Direct detection of Marek's disease virus in poultry dust by loop-mediated isothermal amplification. Arch Virol. 2014;159:3083-7. https://doi.org/10.1007/s00705-014-2157-5.

32. Xu J, Qu C, Tao J. Loop-mediated isothermal amplification assay for detection of Histomonas meleagridis infection in chickens targeting the $18 \mathrm{~S}$ 
rRNA sequences. Avian Pathol. 2014;43:62-7. https://doi.org/10.1080/ 03079457.2013.873112.

33. Barkway CP, Pocock RL, Vrba V, Blake DP. Loop-mediated isothermal amplification (LAMP) assays for the species-specific detection of Eimeria that infect chickens. J Vis Exp. 2015;(96). https://doi.org/10.3791/52552.

34. Staroscik A. Calculator for determining the number of copies of a template. URI Genomics and Sequencing Center. 2004; Available at http://cels.uri.edu/ gsc/cndna.html.

35. Wang $Y$, Wang $H$, Yang $C H$, Wang Q, Mei R. Two distinct manganesecontaining superoxide dismutase genes in Bacillus cereus: their physiological characterizations and roles in surviving in wheat rhizosphere. FEMS Microbiol Lett. 2007;272:206-13. https://doi.org/10.1111/j.1574-6968.2007.00759.x.

36. Gwet KL. Computing inter-rater reliability and its variance in the presence of high agreement. Br J Math Stat Psychol. 2008;61:29-48. https://doi.org/10. 1348/000711006X126600

37. Czopowicz M, Szaluś-Jordanow O, Mickiewicz M, Moroz A, Witkowski L, Markowska-Daniel I, Bagnicka E, Kaba J. Influence of true within-herd prevalence of small ruminant lentivirus infection in goats on agreement between serological immunoenzymatic tests. Prev Vet Med. 2017;144:75-80. https://doi.org/10.1016/j.prevetmed.2017.05.017.

38. Chadfield MS, Christensen JP, Christensen H, Bisgaard M. Characterization of streptococci and enterococci associated with septicaemia in broiler parents with a high prevalence of endocarditis. Avian Pathol. 2004;33:610-7.

39. Hedegaard L, Christensen H, Chadfield MS, Christensen JP, Bisgaard M. Association of Streptococcus pluranimalium with valvular endocarditis and septicaemia in adult broiler parents. Avian Pathol. 2009;38:2013-60. https:// doi.org/10.1080/03079450902737763.

40. Bisgaard M, Bojesen AM, Christensen JP, Christensen H. Observations on the incidence and aetiology of valvular endocarditis in broiler breeders and detection of a newly described taxon of Pasteurellaceae, Avibacterium endocarditidis. Avian Pathol. 2010;39:177-81. https://doi.org/10.1080/ 03079451003758096

41. Stępień-Pyśniak D, Wilczyński J, Marek A, Śmiech A, Kosikowska U, Hauschild T. Staphylococcus simulans associated with endocarditis in broiler chickens. Avian Pathol. 2017;46:44-51. https://doi.org/10.1080/03079457.2016.1203392.

42. Stepien-Pysniak D, Kosikowska U, Hauschild T, Burzynski A, Wilczynski J, Kolinska A, Nowaczek A, Marek a. A loop-mediated isothermal amplification procedure targeting the sodA gene for rapid and specific identification of Gallibacterium anatis. Poult Sci 2018; 0:1-7. Jan 25. doi: https://doi.org/10. 3382/ps/pex420. [Epub ahead of print].

43. Crispo M, Stoute S, Savaris T, Bickford A, Santoro T, Sentíes-Cué CG. Vegetative Valvular endocarditis and hepatitis associated with Helcococcus ovis in a 7-year-old white Leghorn rooster. Avian Dis. 2017;61:526-30. https://doi.org/10.1637/11676-051917-Case.1.

44. Kursa O, Woźniakowski G, Tomczyk G, Sawicka A, Minta Z. Rapid detection of Mycoplasma synoviae by loop-mediated isothermal amplification. Arch Microbiol. 2015;197:319-25. https://doi.org/10.1007/s00203-014-1063-2.

45. Gong J, Zhuang L, Zhu C, Shi S, Zhang D, Zhang L, Yu Y, Dou X, Xu B, Wang C. Loop-mediated isothermal amplification of the sefA gene for rapid detection of Salmonella Enteritidis and Salmonella Gallinarum in chickens. Foodborne Pathog Dis. 2016;13:177-81. https://doi.org/10.1089/fpd.2015.2082

46. Xu X, Zhang S, Wu Q, Zhang J, Li F, Cheng J. Development and application of a loop-mediated isothermal amplification (LAMP) method for rapid and sensitive detection of Enterococcus faecalis in drinking water. J Food Saf. 2014;34:103-10. https://doi.org/10.1111/jfs.12101.

47. Martzy R, Kolm C, Brunner K, Mach RL, Krska R, Šinkovec H, Sommer R, Farnleitner AH, Reischer $\mathrm{GH}$. A loop-mediated isothermal amplification (LAMP) assay for the rapid detection of Enterococcus spp. in water. Water Res. 2017;122:62-9. https://doi.org/10.1016/..watres.2017.05.023.

48. Kato H, Yoshida A, Ansai T, Watari H, Notomi T, Takehara T. Loop-mediated isothermal amplification method for the rapid detection of Enterococcus faecalis in infected root canals. Oral Microbiol Immunol. 2007:22:131-5. https://doi.org/10.1111/j.1399-302X.2007.00328.X.

49. Su J, Liu X, Cui H, Li Y, Chen D, Li Y, Y U G. Rapid and simple detection of methicillin-resistance Staphylococcus aureus by orfX loop-mediated isothermal amplification assay. BMC Biotechnol. 2014;14:8. https://doi.org/10. 1186/1472-6750-14-8.

50. Yamazaki Y, Oba E, Kashiwagi N, Sugita K, Shiiba K, Baba Y, Shimoji Y, Yamazaki W. Development of a loop-mediated isothermal amplification assay for rapid and simple detection of Erysipelothrix rhusiopathiae. Lett Appl Microbiol. 2014;58:362-9. https://doi.org/10.1111/lam.12198.
51. Misawa Y, Yoshida A, Saito R, Yoshida H, Okuzumi K, Ito N, Okada M, Moriya K, Koike K. Application of loop-mediated isothermal amplification technique to rapid and direct detection of methicillin-resistant Staphylococcus aureus (MRSA) in blood cultures. J Infect Chemother. 2007:13:134-40.

52. Otsuka N, Yoshino S, Kawano K, Toyoizumi-Ajisaka H, Shibayama K, Kamachi K. Simple and specific detection of Bordetella holmesii by using a loopmediated isothermal amplification assay. Microbiol Immunol. 2012;56:486-9. https://doi.org/10.1111/j.1348-0421.2012.00465.x.

53. Yamazaki W, Taguchi M, Ishibashi M, Nukina M, Misawa N, Inoue K. Development of a loop-mediated isothermal amplification assay for sensitive and rapid detection of Campylobacter fetus. Vet Microbiol. 2009; 136:393-6. https://doi.org/10.1016/j.vetmic.2008.11.018.

54. Yang $\mathrm{Q}$, Chen $\mathrm{S}$, Ge B. Detecting Salmonella serovars in shell eggs by loopmediated isothermal amplification. J Food Prot. 2013;76:1790-6. https://doi. org/10.4315/0362-028X.JFP-13-140.

55. Wang X, Seo DJ, Lee MH, Choi C. Comparison of conventional PCR, multiplex PCR, and loop-mediated isothermal amplification assays for rapid detection of Arcobacter species. J Clin Microbiol. 2014;52:557-63. https://doi. org/10.1128/JCM.02883-13.

56. Chadfield MS, Bojesen AM, Christensen JP, Juul-Hansen J, Nielsen SS, Bisgaard M. Reproduction of sepsis and endocarditis by experimental infection of chickens with Streptococcus gallinaceus and Enterococcus hirae. Avian Pathol. 2005;34:238-47. https://doi.org/10.1080/03079450500112252.

\section{Ready to submit your research? Choose BMC and benefit from:}

- fast, convenient online submission

- thorough peer review by experienced researchers in your field

- rapid publication on acceptance

- support for research data, including large and complex data types

- gold Open Access which fosters wider collaboration and increased citations

- maximum visibility for your research: over $100 \mathrm{M}$ website views per year

At BMC, research is always in progress.

Learn more biomedcentral.com/submissions 